\title{
Trademark Protection, Absolute and Relative Grounds for Refusal of Trademark
}

\author{
Safet Emruli \\ $\mathrm{PhD}$ in law, professor at Faculty of law, State University of Tetova, St. \\ Ilinden nn, 1200 Tetovo, Republic of Macedonia \\ Agim Nuhiu \\ $\mathrm{PhD}$ in law, professor at Faculty of law, State University of Tetova, \\ St. llinden nn, 1200 Tetovo, Republic of Macedonia \\ Besa Kadriu \\ MSc in law, Faculty of law, South East European University, \\ St. Ilinden no 335, 1200 Tetovo, Republic of Macedonia
}

\begin{abstract}
A trademark is a sign that individualizes the goods of a given enterprise and distinguishes them from the goods of its competitors. Trademark may consist letters, words, slogans, symbols, numerals, pictures, name, logo, even sounds and smell. They are based on registration. One registered trademark gives to his owner the right to exclude others from using an identical or similar mark to identify its goods or service on market. Trademark owners should apply for registration by filling an application in national level, in their national office for protecting trademark rights which trademark will be protected only in that current country and in international level by filling one application where his trademark will be protected in many country depending in which country he has mark the protection. The law does not recognize every possible mark or symbol as a valid trademark, there are some criteria that one sign or mark have to satisfy to gain the trademark protection. Any sing which is not able to distinguish the goods and services can not be registered, and this is one of the reasons for rejection of registration. Sign or mark must be a "trademark", must not fail on the absolute and relative grounds. Sign can be refusal for absolute ground if is not able to distinguish the goods and services. Unprotected mark will be consider also mark in conflicts with a prior right in another trademark or other distinctive sign will also be refusal, in this case for relative ground. Accordantly to this, the owner, during creating his mark should be original, natural, creative etc.
\end{abstract}

Keywords: trademarks, protection of trademark, absolute ground for refusal, relative ground for refusal.

\section{Trademark}

The formal definition for trademark as defined under the Agreement on Trade-Related Aspects of Intellectual Property Rights (TRIPS) is that it could be: any sign or any combination of signs, capable of distinguishing the goods or services of one undertaking from those of other undertakings. ${ }^{1}$

\footnotetext{
${ }_{1}^{1}$ Agreement on Trade-Related Aspects of Intellectual Property Rights, Apr. 15, 1994, Marrakesh Agreement Establishing the World Trade Organization, Annex $1 \mathrm{C}$
} 
The sing, may consist letters, words, slogans, symbols, numerals, pictures, name, logo, in modern age even sounds and smell, which in itself have two main characteristics: they should be distinctive and should not be descriptive.

\section{Example:}

Words ( words Trademark): Coca cola, Sony, Ford, Apple, Philips, Levs.

Logos (figurative trademark):
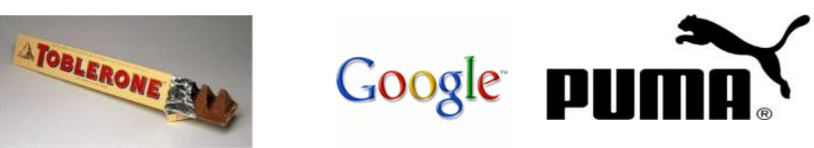

3-D trademarks

Sounds trademark:

Yes: $\sqrt{ }$

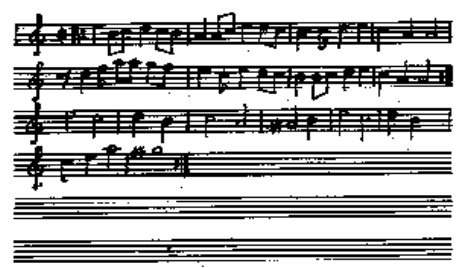

No: $X$

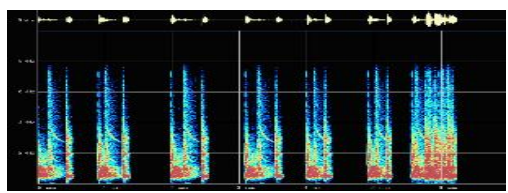

Sign must be distinctive, able to be easily distinguished from the identifying features of the products and services of other producers. ${ }^{1}$ It means it must be very natural and capable to distinguish.

Descriptiveness means when the mark gives information regarding the product and services to the consumers. Descriptive marks are considered those which give exclusive rights to some potential symbols that may interfere with the rights of competing merchants to freely describe their goods and communicate with the public. ${ }^{2}$ The law dose not permit registration of descriptive trademark. Giving legal protection and exclusive rights of marks with descriptive character will cause a monopoly in market and limiting its usage for other competitors on the market. Monopolization of market is one of the biggest reasons why descriptive words or signs should not be protected as e trademark.

According to this, most important characteristics of a trademark is its distinctive character.

\section{Economic point of view of trademark}

Trademark can be considered as instrument of connection between the producers and consumers.

\footnotetext{
1 C. Colston \& K. Middleton, "Modern Intellectual Property Law" Second Edition, London, Sydney Portland, Oregon, p. 505

2 R. SCHECHTER and J. THOMAS, Intellectual Property the Law of Copyrights, Patents, and Trademarks, Thomson West, USA, 2003, p. 571
} 
The most common use of trademark is in consumer advertising to promote product sales, but trademark use has become increase

ingly sophisticated and varied. Promotion of product sales and cementing customer loyalty, trademarks help their owners increase profitability, respond to unfair competition, expand and maintain market share, differentiate products, introduce new product lines, gain royalties through licensing programs, support strategic partnership and marketing alliances, and justify corporate valuation in financial transactions. ${ }^{1}$

\section{Trademark Protections}

A trademark protects the right to distinguish the owner's goods or services from other goods or services from another owner's. ${ }^{2}$ Trademark protection provides exclusive right to owners. It means that the protection gives the right to the owner to exclude others parties from using his mark or imitation of his mark for goods or services that do not originate from him.

Trademark right is limited, it can be protected for next 10 years with possibility of renewable 10 years intervals. ${ }^{3}$

Trademark rights are purely territorial in scope. ${ }^{4}$ There are two ways of protection of trademark, national protection and international protection of trademark.

\section{National Protection}

Marks can be reiterated in each state. ${ }^{5}$ National protection of trademark is when the applicant applies for protection in one current state or territory in their national office. Examiners will examined if the sign fulfils the requirements in accordance with national legislation. The protection of this trademark is valid only in the territory in which protection is asked for.

The procedure for the protection of national trademarks is regulated by the national law and by their implementing regulations. If the sign meets the requirements of those laws and regulation in national level than the sign will get the protection.

\section{International Protection}

International registration of trademarks simplifies the procedure of obtaining a trademark registration in more than one country by filling one application. Protection of international registration of trademark is regulated with Madrid Agreement and the Madrid Protocol and it is known as a Madrid system of protection.

Madrid Agreement was signed in 1891 and provides for protection of marks in many countries which obtain an international registration valid in each contracting party. According to this, nationals of any of the contracting countries may, in all the other countries party to this Agreement, secure protection for their marks applicable to goods or services, registered in the country of origin, by filing the said marks at the International Bureau of Intellectual Property (hereinafter designated as "the International Bureau") referred to in the Convention establishing the World Intellectual Property Organization (hereinafter designated as "the Organization"), through the intermediary of the Office of the said country of origin. ${ }^{6}$

It means that international registration is when the trademark owner applies to gain registration in member countries, each of which apply their own rules and laws to determine whether or not the mark may be protected in their jurisdiction. As we can see the Madrid system offers protection to users of trademark applying for protection in a number of countries at the

\footnotetext{
${ }^{1}$ K. Idris, Intellectual Property: A Power Tool for Economic Growth, p. 18

${ }^{2}$ A. L. Brookman, Trademark law, Second Edition, 2015 USA, p.4

3 article 18 of TRIPS Agreement has set minimum terms of years for duration of protection

${ }^{4}$ B.M. Barkoff and A.C. Selden, Fundamentals of Franchising, Third Edition, 2008, USA, p.44

5 L. Brookman, Trademark law, Second Edition, 2015 USA, p.4

${ }^{6}$ MADRID AGREEMENT CONCERNING THE INTERNATIONAL REGISTRATION OF MARKS, article 1, point 2, avelable online: http://www.wipo.int/edocs/lexdocs/treaties/en/madrid-gp/trt_madrid_gp_001en.pdf 
same time. When we say number of countries it means all countries which are contracting parties to this treaty including the countries out of European continent.

By international protection of trademark applicant or owner of trademark dose not have to go in many countries, to fill application in many languages and to pay a separate fees in each office, here he has to fill one application for protecting his trademark.

Applicant should apply for international protection at International Bureau of World Intellectual Property Organization (WIPO) in Geneva.

In an other hand we have also have a community trademark (CTM). CTM is a unitary mark for every Member State of EU. 1 Office of Harmonization for the Internal Market (OHIM) simplifies the procedure for obtaining trademark protection in the EU especially for a person who does business in more than one EU country. By filing one CTM, the applicant can obtain trademark protection in all countries of the EU. The number of member countries of the EU has reached 28 with the accession of Croatia as of July 1, 2013. This means a CTM can provide trademark protection in all 28 countries. EU has 24 official languages, so applicant applying for a CTM can fill out the trademark application in any these 24 official languages. However, the applicant, would still have to translate the application into one of the five official languages of OHIM which are English, French, German, Italian and Spanish. As we can see there are five official working languages of OHIM.

Each of the EU member states actually has their own trademark laws but which must also be compatible and harmonized with the First Trade Marks Directive. ${ }^{2}$ CTMs are regulated by the Community Trademark Regulation (CTMR). Even if regulation has effects in EU territories, it dose not replace national trademark laws.

\section{Absolute and relative grounds for refusal of trademark}

During the process of registration, trademark is examined for absolute grounds for refusal. Any sing which is not able to distinguish the goods and services can not be registered, and this is one of the reasons for refusal of registration.

The law does not recognize every possible symbol as a valid trademark. A registrable mark must satisfy three criteria:

It must be a "trade mark"

It must not fail on the absolute ground and

It must not fail on the relative ground. ${ }^{3}$

If one mark satisfies these criteria it will be registrable and protected for 10 years with possibility of renewable 10 years intervals, other way it will lend in refusal for absolute and relative grounds.

Absolute grounds of refusal prevent registration prima facie, relative grounds for refusal deal with the mark in connection to other marks.

\section{Absolute grounds for refusal of trademark}

Sign may be refused for absolute ground if there is lack of distinctiveness, descriptiveness, generic.

\footnotetext{
${ }^{1}$ C. Colston, Principles of Intellectual Property Law, 1999, London, p. 374

2. F. ABBOTT, TH. COTTIER and F. GARRY, International Intellectual Property In An Integrated World Economy, Second Edition, USA, 2011

${ }^{3}$ C. Colston, Principles of Intellectual Property Law, 1999, London, p. 374 
The absolute ground for refusal prevent, in general, marks that are purely descriptive, functional or objectionable for being registered. ${ }^{1}$

Article 3 of Trade Mark Directive (TMD) sets out the absolute ground for refusal of trademark registration. Accordantly to this, any application for trademark protection which can not satisfy the following requirement, will be rejected for absolute grounds:

A sign must constitute a trademark or capable of graphic representation (Article 3/1. a)

A trademark must have a distinctive character (Article 3/1. b)

Must not be descriptive (Article 3/1. c)

Must not be customary in current language (Article 3/1. d)

Furthermore, trademark is not resistible for the same reasons if it is contrary to public policy or is deceptive.

Trademarks which are devoid of any distinctive character shall not be registered or, if registered, shall be liable to be declared invalid2, says article 3. 1. b of Trade Mark Directive (TMD), same as Article 7/1(b) of the Community Trade Mark Regulation (CTMR) which consider a lack of distinctive character as an absolute grounds for refusal.

Same treatment have a mark which give information to customers for goods and services or are directly connected with goods and services, these are considered as descriptive trademark and will be refused for absolute grounds for refusal. A descriptive mark might reveal something about the ingredients of the product, or its properties, or about the likely users of the product. ${ }^{3}$

"ORANGE" or "FRUIT" for oranges, it would interfere with the ability of other greengrocers to convey information about their oranges. ${ }^{4}$ Monopolization of a word is one of the biggest reasons why a descriptive mark should not be registered.

Generic marks are also not protected, they are common names for the kind of product instead of including the source of the product. ${ }^{5}$ Word "Apple" for fruit can not be consider as a trademark, it will be consider as a generic for type of fruit, but word "Apple" for computers can be use as trademark because word apple as no connection with computers, electric goods.

\section{Relative grounds for refusal of trademark}

Relative grounds for refusal deal with the sign in connection to other marks.

Mark in conflicts with a prior right in another trademark or other distinctive sign will also be rejected for relative ground.

Sign which is identical or similar kind of goods or services which would create confusion at the average consumer, with an earlier trademark including the possibility of association to earlier trademark will not be protected as a trademark base on relative grounds for refusal.

Provisions regarding relative ground can be founded in Article 8 of CTMR and Article 4 of TMD.

${ }^{1}$ C. Colston, Principles of Intelectual Property Law, 1999, London, p. 357

2 Article 3.1.b, Trade Mark Directive, available online: http://www.wipo.int/edocs/lexdocs/laws/en/eu/eu056en.pdf

${ }^{3}$ R. SCHECHTER and J. THOMAS, Intellectual Property the Law of Copyrights, Patents, and Trademarks, Thomson West, USA, 2003,

p. 575

${ }^{4}$ L. BENTLY-B. SHERMAN, Intellectual Property Law, Oxford University Press, Oxford, 2004, p.832

5 D. Friedmann, Trademark and Social Media Algorithmic Justice, USA, 2015, 167 
For more, rights with higher priority to similar trademark filed for identical goods or services where the likelihood of confusion on the part of the public exists, which includes the likelihood of association with the earlier trademark. ${ }^{1}$ In case of this, the injured party has the right for opposition.

Example:

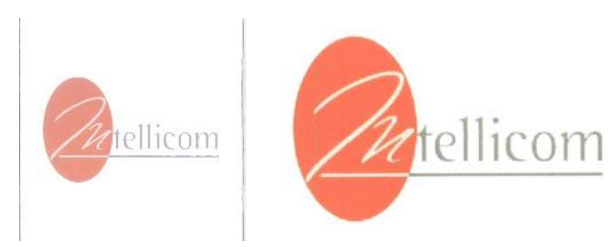

Identical :

\section{Conclusion}

If a sign meets all requirements for protecting a trademark, it will be accepted and will be registered as a protected trademark. Trademark will be protected for 10 years with possibility of renewal by paying the fees again in every 10 years.

International registration of trademarks simplifies the procedure of obtaining a trademark registration in more than one country by fulfilling one application

Trademark protection is territorial, but, the procedure of obtaining a trademark protection now is simplified by giving the chance to applicants to apply with one application in many counties.

Otherwise, if trademark will not satisfy the requirements in accordance of legislation for protection of trademark, it will be refused or rejected depends on which requirements dose not meet. They can be absolute and relative ones.

Absolute grounds of refusal prevent registration prima facie, relative grounds for refusal deal with the mark in connection to other marks.

Regarding to this, sign must be original, creative, remarkable in the market, non descriptive, distinctive or different to become a trademark.

\section{Bibliography}

\section{Books:}

F. ABBOTT, TH. COTTIER and F. GARRY, International Intellectual Property In An Integrated World Economy, Second Edition, USA, 2011

B. M. Barkoff and A. C. Selden, Fundamentals of Franchising, Third Edition, 2008, USA, p. 44

A. L. Brookman, Trademark law, Second Edition, 2015 USA

1 T. C. Jehoram, C. van Nispen, T. Huydecoper, European Trademak Law: Community Trademark Law and Harmonized National Trademark Law, 2010, p. 183 
L. Brookman, Trademark law, Second Edition, 2015 USA

C. Colston, Principles of Intellectual Property Law, 1999, London

C. Colston \& K. Middleton, "Modern Intellectual Property Law" Second Edition, London, Sydney Portland, Orego

D. Friedmann, Trademark and Social Media Algorithmic Justice, USA, 2015

K. Idris, Intellectual Property: A Power Tool for Economic Growth

T. C. Jehoram, C. van Nispen, T. Huydecoper, European Trademak Law: Community Trademark Law and Harmonized National Trademark Law, 2010

R. SCHECHTER and J. THOMAS, Intellectual Property the Law of Copyrights, Patents, and Trademarks, Thomson West, USA, 2003

L. B-B. SHERMAN, Intellectual Property Law, Oxford University Press, Oxford, 2004

Laws and Treaties:

Agreement on Trade-Related Aspects of Intellectual Property Rights, Apr. 15, 1994, Marrakesh Agreement Establishing the World Trade Organization

MADRID AGREEMENT CONCERNING THE INTERNATIONAL REGISTRATION OF MARKS, article 1, point 2

Article 3. 1. b, Trade Mark Directive 